\title{
The New Depository Program and College Libraries
}

\begin{abstract}
Qualifications to be met by depository libraries under the new law are outlined, and a brief survey is presented of the conditions leading to its enactment. The range of publications issued by the Superintendent of Documents is described, as are current efforts to bring a selection of non-GPO publications under the depository provision. Statistics are given on the cost of government publishing, the extent of distribution, and the number of depository libraries.
\end{abstract}

$\mathrm{T}_{\mathrm{r}}$ he New Depository Program has resulted from the enactment by Congress on August 9, 1962, of Public Law 87579 , known as the Depository Library Act of 1962. There had been a depository library distribution program before that time, of course. As a matter of fact, legal provision has existed since 1857 for distributing government publications to certain designated libraries.

Qualifications and requirements for a depository library are relatively simple. There must be a collection of ten thousand volumes other than government publications, and the government publications selected must be made freely available for public use. A library must have the facilities for providing adequate custody and service for the depository collection. A report of the condition of the library to the Superintendent of Documents is required at least every two years. Finally, publications

Mr. Buckley is Superintendent of Documents, U.S. Government Printing Office, Washington, D.C. selected may be disposed of only as provided for by the law.

A basic point often misunderstood is that all depositories must be selective under the law, and that selection of a publications series or other category serves to make available to the depository one copy of each publication subsequently printed in that series or category. Publications cannot be made available for depository distribution on a retroactive basis.

There seems also to be widespread belief that a library may be designated a "partial depository" apart from the structure provided by the depository law. A partial depository is merely one which does not select all of the publications made available for depository distribution. Relatively few libraries are in a position to make the complete selection, which now encompasses some twelve thousand publications a year, excluding congressional bills and resolutions.

By 1962 the existing depository system, dating basically from 1895, had 
reached a point where new and modern libraries were sometimes unable to be designated as depositories, despite the fact that they had grown up in areas that had become economically or educationally important because of population or industrial shiftings. The one depository permitted in each congressional district was occasionally occupied by a formerly important library which had become, with the passage of time, among the smaller and less active in the area. The spoils system had been removed from the depository program by a law enacted in 1913 whereby a depository, once designated, continues in that status as long as it meets the requirements of law.

In making provision for increasing the number of Representative depository designations for each congressional district from one to two, and for each Senator from one to two on an at-large basis for the state, Congress attempted to remedy this situation in the 1962 law. It also sought to ease the storage space problems, of the smaller depositories in particular, through a provision for regional depositories in each state which would retain complete collections permanently and offer loan and reference services to the other depositories, which are then permitted to dispose of publications after a certain number of years.

College and university libraries have always been a prominent part of the depository system. The college student today must have a knowledge of the effects and the importance of the study and research in which the United States government is constantly engaged in so many fields, and how the lives of all of the citizens of this nation are affected by it.

It is not surprising therefore to find that, of the first 127 additional depositories designated under provisions of the new Depository Law, eighty were college or university libraries. It is signif- icant that there is active demand for and use of government publications by students and faculties alike. It might seem surprising that some of the publications of greatest value to the scholar are those which have received little publicity or popular acclaim. It is even possible that some might be among the highly technical or complex titles that are occasionally lampooned or otherwise criticized in the public prints. Their practical value could be negative to the manufacturer, industrialist, or businessman, with the only apparent tangible result being the expenditure of the funds which the project entailed. To the advanced student or scientist, however, these negative conclusions can save a repetition of the time and effort which went into them at the time of the original research. The Superintendent of Documents and the Government Printing Office do not, of course, determine, nor do they have any jurisdiction over, the subject matter, title, or necessity for the issuance of the publications that they distribute.

The responsibility of administering a program of the magnitude of that involved in distributing government publications to 792 depository libraries, a number which will increase as the years go by, is a great and costly one for the United States government as well as for the libraries. If a college library contemplates seeking designation as a depository, it should examine carefully and unselfishly its potential for maintaining and servicing a permanent collection of government documents and encouraging the maximum use of that collection. It should have trained personnel who are familiar with government publications and depository procedures. In the hands of competent professional documents librarians, we feel that a majority of depository problems can be solved within the general guidelines which are estab-

(Continued on page 70 ) 


\section{THE NEW DEPOSITORY PROGRAM AND COLLEGE LIBRARIES}

(Continued from page 18)

lished in implementing the law. Too often, remedies which are available within these flexible provisions have not been used. At the same time, a considerable number of librarians have expressed their disappointment that a great many more detailed rules and regulations have not been promulgated covering almost every conceivable aspect of depository operation under provisions of the law.

During the current year, the Superintendent of Documents expects to distribute more than six million copies of publications to depository libraries. His staff is constantly refining breakdowns for selection, as far as possible, to provide librarians with the means of selecting specific material without the necessity of including also, other publications for which they do not have a need. This

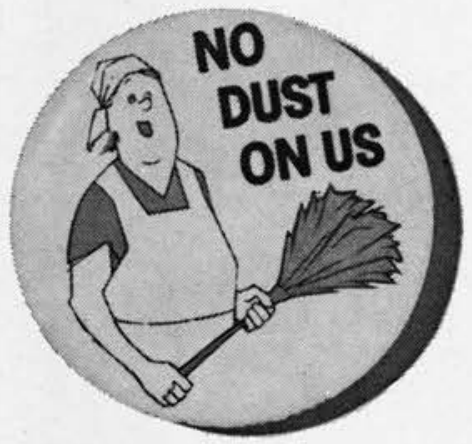

SEE PAGES 4-5 was formerly a much greater problem, particularly in the category of general publications. While emergency needs can still cause an agency to include diverse and unexpected issuances in such a category, there is a definite trend toward their separation of similar or recurring issuances into particular series.

As it becomes possible to identify, with the help of the issuing government agencies, their publications not printed by the Government Printing Office that also come within the depository program for the first time under the 1962 depository law, and as the agencies are able to make available these publications in sufficient quantity, the Superintendent of Documents will begin including them among those offered to depository libraries for their selection. There have been many conflicting accounts of the efforts necessary to implement this far reaching and new provision of the depository distribution program. The concern at the Government Printing Office has been whether it would be possible to carry out this provision of the law, since there is absolutely no control over the publications involved. A tremendous problem of initial screening is necessary. Everyone admits that, of some $\$ 100,000,000$ worth of printing done each year by United States government agencies outside the Government Printing Office, only a relatively small percentage will be needed by the depositories. After that portion is identified, many government agencies will face the problems imposed by limitations of their resources which may affect their ability to produce the additional copies that would be required for distribution, as well as to transport them to the Government Printing Office in quantity from production points located all over the world. We are attempting to make a modest beginning in the forthcoming fiscal year, 
with the publications of two agencies, the Department of the Interior and $\mathrm{Bu}$ reau of the Census. From the experience of this effort we hope to secure data which will help both our office and the issuing government agencies as this monumental task continues and expands in the years ahead.

College libraries which are federal depositories have a joint responsibility with the office of the Superintendent of Documents for making available the essential information provided by publications of the United States government. The new depository law provides for an expanded number of collections to be used by those who need them; an improved administrative structure and opportunity for better service, through the provision for regional depositories; and a future which offers interesting possibilities, despite the serious problems involved, for an extension of the type of government material that these libraries can offer to their students and other scholars who may need them.

\section{Committee on Library Surveys Conference}

The ACRL Committee on Library Surveys and Columbia University will have a conference on June 14-17 at Columbia. Tentative conference topics include types and purposes of surveys, sources of information, and applications to types of libraries; and some practical problems.

\section{NOTE}

\section{Address Change}

The editorial, advertising, and production offices of CHOICE: Books for College Libraries moved to larger quarters on December 31 . The new address is 42 Broad Street, Middletown, Conn. 06458. The new telephone number is (203) 347-6933.

\section{ACRL MEMBERSHIP December 31, 1964}

Total $\ldots \ldots \ldots \ldots \ldots .8,874$

Subject Specialists . . . . 1,468

Junior College . . . . . . . . 699

Teacher Education . . . . . . 506

University $\ldots \ldots \ldots \ldots \ldots 3,035$

College $\ldots \ldots \ldots \ldots \ldots 2,345$

Rare Books ......... 726

Institutional

Memberships $\ldots \ldots \ldots 1,662$

Please note that many members do not select membership in sections although two section memberships are available without extra charge. 